\title{
Does soil color affect fish evolution? Differences in color change rate between a lineages of the sailfin tetra
}

Correspondence:

Kalebe S. Pinto kalebedsp@gmail.com
Submitted August 19, 2019

Accepted March 23, 2020 by George Mattox Epub Jun 12, 2020

\author{
${ }^{\oplus}$ Kalebe S. Pinto $1,{ }^{\oplus}$ Tiago H. S. Pires ${ }^{1},{ }^{\oplus}$ Gabriel Stefanelli-Silva ${ }^{2}$, \\ ${ }^{\oplus}$ Bruno S. Barros $3{ }^{3}{ }^{\bullet}$ Elio A. Borghezan ${ }^{4}$ and ${ }^{\oplus}$ Jansen Zuanon ${ }^{1}$
}

Several organisms match their skin color to the prevalent background color, granting crypsis against predators. The rate at which body color changes occur varies among organisms as a result of physiological constraints and adaptation to variation in contrasts between objects and the environmental background. Faster darkening of body color is favored in environments that show higher amounts of contrast between common objects and the prevailing background. Soil types in Amazon forest streams (igarapés) create distinct environments with respect to the amount of contrast, a result of the amount of sand and clay, which offers different contrasts against dead leaves. Here, we investigated differences in the rates of color change among populations of the sailfin tetra (Crenuchus spilurus) that represent lineages that live in regions of different soil types. Populations inserted into blackwaters (sandy soil) showed higher rates of color darkening in response to exposure to a dark environment composed by dead leaves. We propose that natural selection stemming from predation can favor faster color change rate in environments where there is higher variability of contrasts between leaf litter and soil, which is common in most blackwater streams.

Keywords: Background matching, Body color, Crenuchus spilurus, Crypsis, Phenotypic plasticity.
Online version ISSN 1982-0224

Print version ISSN 1679-6225

Neotrop. Ichthyol.

vol. 18, no. 2, Maringá 2020
1 Laboratório de Ecologia Comportamental e Evolução, Instituto Nacional de Pesquisas da Amazônia, Av. André Araújo 2936, Petrópolis, 69067375 Manaus, AM, Brazil. (KSP) kalebedsp@gmail.com, (corresponding author); (THSP) thspires@gmail.com; (JZ) jzuanon3@gmail.com.

2 Laboratório de Ecologia e Evolução de Mar Profundo, Instituto Oceanográfico, Universidade de São Paulo, Praça do Oceanográfico 191, Butantã, 05508120 São Paulo, SP, Brazil. gabrielstefanelli@hotmail.com.

3 Campus José Ribeiro Filho, Universidade Federal de Rondônia, BR 364, Km 9.5, 76801059 Porto Velho, RO, Brazil. brunim_s@hotmail.com.

4 Wildlife Research Center of Kyoto University. 2-24 Tanaka-Sekiden-cho, Sakyo-ku, 6068203 Kyoto, Japan. borghezan.ea@gmail.com. 
Diversos organismos combinam sua coloração corporal com a cor de fundo predominante no ambiente, conferindo cripticidade contra predadores. A taxa na qual as mudanças de coloração corpórea ocorrem varia entre os organismos como resultado de restrições fisiológicas e adaptação à variação de contrastes entre objetos e o ambiente. O escurecimento mais rápido da cor do corpo é favorecido em ambientes que mostram maiores quantidades de contraste entre objetos comuns e o fundo predominante. Tipos de solo em igarapés da floresta amazônica criam ambientes distintos em relação à quantidade de contraste, resultado da quantidade de areia e argila, que oferece diferentes contrastes contra folhiço submerso. Nós investigamos as diferenças nas taxas de mudança de cor entre populações do tetra-colibri Crenuchus spilurus que representam linhagens que vivem em regiões de diferentes tipos de solo. Populações inseridas em águas pretas (solo arenoso) apresentaram maiores taxas de escurecimento da cor em resposta à exposição ao ambiente escuro de folhiço submerso. Nós propomos que a seleção natural decorrente da predação pode favorecer uma taxa de mudança de cor mais rápida em ambientes onde há maior variabilidade de contrastes entre o folhiço submerso e o solo, o que é comum na maioria dos igarapés de águas pretas.

Palavras-chave: Coloração corporal, Crenuchus spilurus, Cripticismo, Similaridade ao plano de fundo, Plasticidade fenotípica.

\section{INTRODUCTION}

Reversible darkening or lightening of the skin color are common to many organisms (Sugimoto, 2002; Leclercq et al., 2010). Such modification of body coloration can serve many purposes, such as in thermoregulation (Silbiger, Munguia, 2007; Munguia et al., 2013), signaling during contests and courtship behavior (Agrawal, 2001), but is more commonly reported as an antipredator mechanism (Sumner, 1935a,b; Whiteley et al., 2011).

Many fish species adjust their body color as a response to the prevalent background (Fingerman, 1965; Healey, 1999; Hemmi et al., 2006; Zuanon et al., 2006; Stevens, Merilaita, 2009; Stevens et al., 2013, 2014). Such background matching occurs through the expansion or retraction of melanophores, which are responsible for increasing or decreasing the exposure of melanin on the surface of the skin (Fugii, 2000; Logan et al., 2006; Stuart-Fox, Moussalli, 2009).

Although a fast response of the melanophores to changes in the environment may represent an important advantage against predation (Fuller, Berglund, 1996), the rate at which the response occurs can be constrained by neural and physiological mechanisms, especially because fast and precise dissipation of signaling molecules from the sensory system to the melanophores can be complex (Tuma, Gelfand, 1999). As such, investment in crypsis can be costly and considered a trade-off against energy resources that could be allocated to other aspects of the life cycle (Carrascal et al., 2001; Kekäläinen et al., 
2009). Therefore, the rate at which skin color changes can vary among species as a result of natural selection, which is expected to favor faster rates in environments that show greater variation in contrast between objects (e.g. plant material, rocks) and the predominant background (e.g. soil).

Soil types in the Amazon are highly diverse, especially due to the different degree of weathering observed between recent geological formations (such as the Andean cordillera) and older cratonic regions (Guyana and Brazilian shields) (Quesada et al., 2011). River avulsion (i.e. abandonment of the river channel and formation of a new one) and aggradation (i.e. land elevation in a riverine system), in turn, may create new areas, which retain the previous soil type, further increasing the heterogeneity of the soil landscape (Räsänen et al., 1992; Hayakawa, Rossetti, 2015). As such, small Amazonian forest streams (locally termed igarapés) may flow on soil types that are typical of whitewater floodplains, such as clayey, nutrient-rich gleysols and fluvisols (Sombroek, 1984). In contrast, streams flowing on sandy, weathered ferralsols and podsols are typical of blackwater environments (Klinge, 1965; Janzen, 1974). Such difference in soil composition and color gives distinct contrasts between typical leaf litter and the predominant background in each environment.

The sailfin tetra Crenuchus spilurus Günther (Characiformes: Crenuchidae) is a small fish (maximum $6 \mathrm{~cm}$ ) that lives predominantly in first and second order igarapés (Pires et al., 2016). This species can be subdivided into two main lineages, one constrained to the largest blackwater environment of the world (rio Negro basin) and a second distributed throughout the remainder of the Amazon, termed Negro lineage and Amazonas lineage, respectively (Pires et al., 2018; 2019). We hypothesized that the two lineages differ in the rate of body color darkening, which could arise from natural selection based on the distinct contrasts observed in their natural habitats.

\section{MATERIAL AND METHODS}

Soil and leaf litter samples were taken from two environments where populations of C. spilurus from the two main lineages are found. We used a spectrometer (Ocean Optics, USA) and a full spectrum light source (ADA, Japan) to measure the reflectance of soil samples from each environment and common leaf litter (Fig. 1). This simple measure highlighted the greater amount of contrast between an object (dead leaf) and background (soil) in the sandy environment.

We sampled individuals of C. spilurus from four localities, two of which harbor populations from the Negro lineage ( $3^{\circ} 6{ }^{\prime 2} 2.94$ "S, 59 58'42.48”W; $2^{\circ} 23$ '25.52”S, $\left.60^{\circ} 10^{\prime} 15.13^{\prime} \mathrm{W}\right)$, while the other two harbor populations from the Amazonas lineage ( $8^{\circ} 41^{\prime} 0.00^{\prime}$ 'S, 6351'0.00”W; 350'25.30”S, 73²2'51.60”W) (Fig. 2).

Fish were kept under laboratorial conditions in $60 \times 40 \times 20 \mathrm{~cm}(72 \mathrm{~L})$ tanks, separated by population. Light regime was similar to the natural environment, with natural light provided by windows covering more than half of a laboratory wall. Temperature was kept at $24{ }^{\circ} \mathrm{C}$ using air conditioners, simulating a typical igarapé thermic environment (Espírito-Santo et al., 2018; Pires et al., 2018). Each tank contained individual air pumps and filtering system. Most importantly, sand was used as a substrate for all stock tanks. 


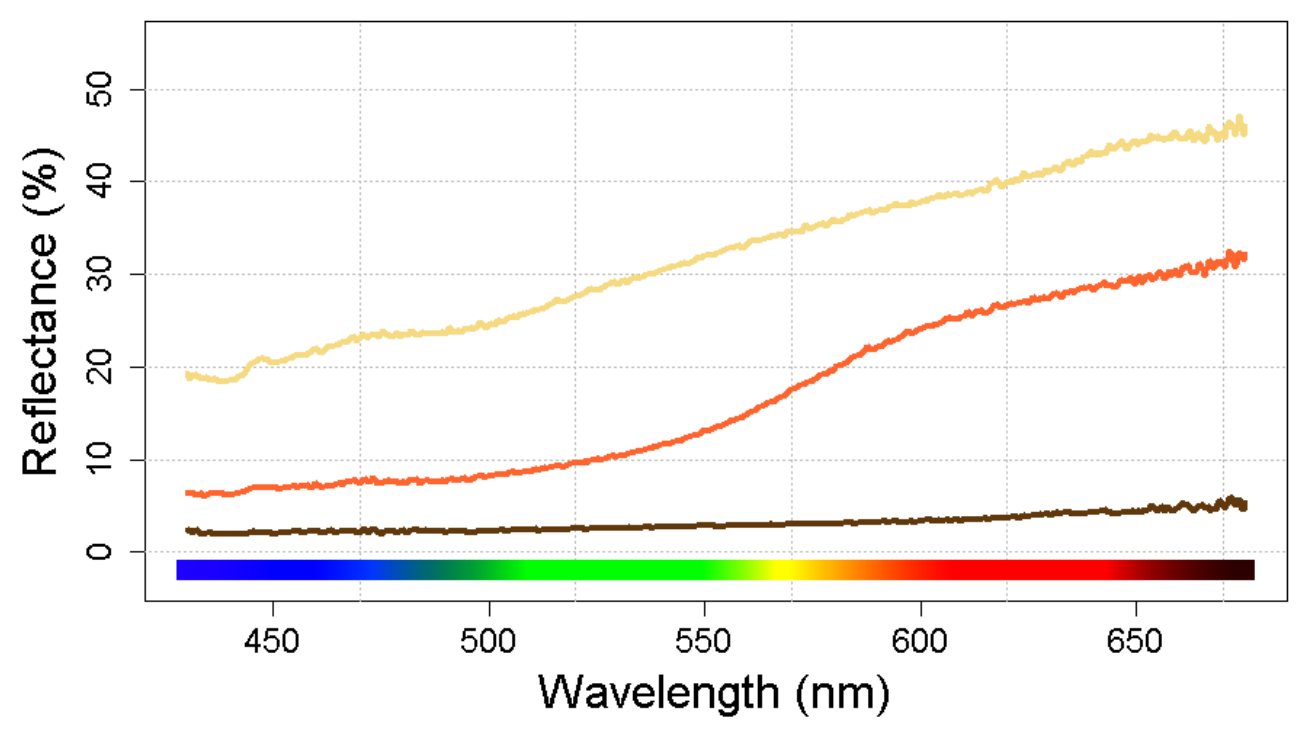

FIGURE 1 I Reflectance of the types of substrates commonly found in igarapés in the Amazon forest: dead leaves (brown), clay (orange) and sand (yellow). The strong dissimilarity between white sand and dead leaves creates a higher contrast at the environment.



FIGURE 2 I Map showing the geographical position of the four populations of Crenuchus spilurus used in this study. Shapes represent the two main lineages that each population represents; squares for the Negro lineage and circles for the Amazonas lineage. Classification of lineages follows Pires et al. (2018).

Experimental set-up. We used a $60 \times 20$ x $20 \mathrm{~cm}$ tank for experimental procedures. We placed soaked dead leaves taken from a natural igarapé environment to form the 
substrate, and filled the tank with 241 of water. The dead leaves substrate was maintained for all individuals tested. The tank was segmented into three sections using glass plates. Another glass plate was used to further subdivide the central compartment into two, resulting in a $10 \times 20 \times 20$ central compartment that housed the fish during experimental procedures. This set-up was built to increase the chances that light reaching the fish's eyes would be reflected from the leaf litter. A 40-watt incandescent light bulb was placed $60 \mathrm{~cm}$ directly above the central compartment (Figs. 3a-b).

We placed a photo camera (Nikon D90, coupled to $60 \mathrm{~mm}$ lenses) on a fixed tripod $50 \mathrm{~cm}$ away from the experimental tank. We transferred individual fish from the stock tank to the central compartment of the experimental tank using a fish net. We took photographs of the fish every 5 seconds during 10 minutes. After that, individuals were measured using a digital caliper and transferred to another 721 stock tank. All pictures were taken using the same custom camera configuration and saved in RAW format (without color processing).

Data sampling. We measured 56 fish: 28 from the Negro lineage (15 from the eastern population and 13 from the northern population) and 28 fish from the Amazonas lineage (15 fish from the westernmost population and 13 from the southern population). Color calibration was conducted using a standard color target (X-rite ColorChecker Passport) and the software Agyll Color Management System (Bergman, Beehner, 2008). The open source software Darktable was used to convert images to BMP files after color calibration. We used the free software Gpick to extract five RGB values from the dorsal region of the fish for each picture (Stevens et al., 2007). We converted RGB values to the CMYK system and retained only $\mathrm{K}$ (black) values as a proxy for melanin expression (Sacchi et al., 2013; Gilby et al., 2015).

Body darkening. For each fish, we conducted linear regressions using $\mathrm{K}$ values as the dependent variable and the order in which the pictures were taken (chronologic sequence of image acquisition) as the independent variable. We extracted the regression

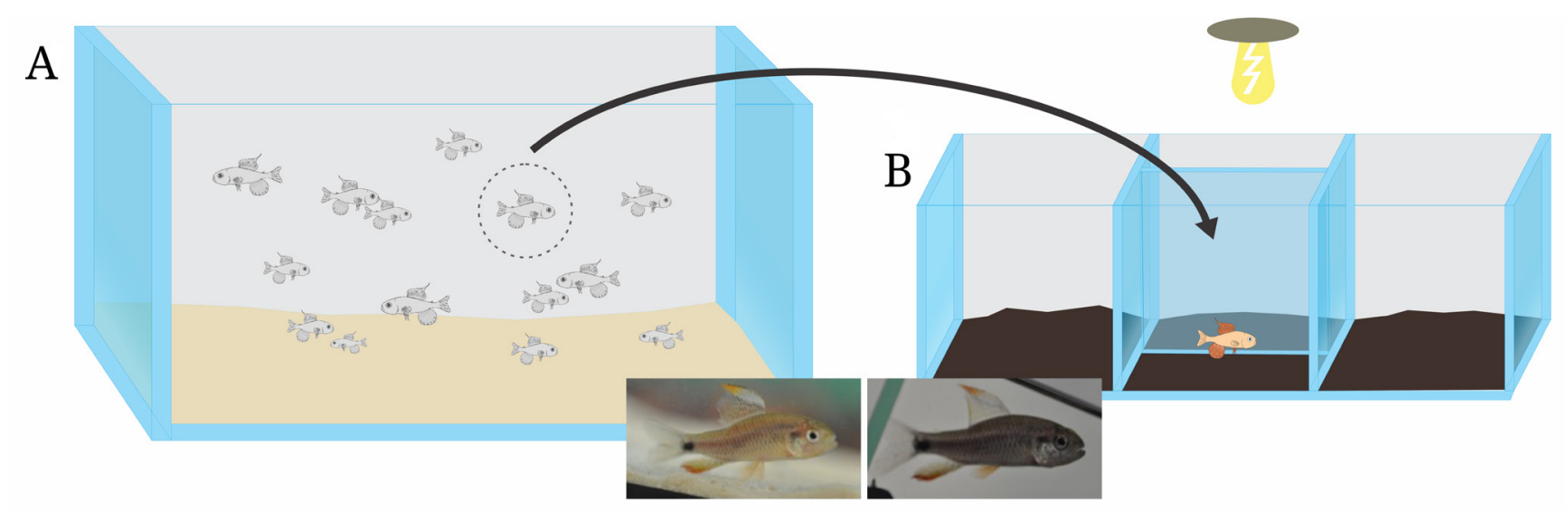

FIGURE 3 I A. Representation of the stock tank, with sandy bottom. B. Representation of experimental tank showing the compartments, leaf litter bottom and light bulb. Inner panes: pictures of fish with bright coloration (in stock tank) and dark coloration (after ten minutes of exposure to leaf litter bottom). 
slope (b) as a measure of color change rate. We contrasted color change rates with the size of the individuals and among populations using an ANCOVA and Tukey's HSD post-hoc test.

Color change. We also investigated the changes in raw RGB values among populations and across trials. To that end, we categorized the RGB values into "Initial" and "Final" moments of the trials. Initial values were the average of the first five measurements of body color; and the last five RGB measures were classified as "Final". We then conducted a two-way MANOVA to contrast RGB values against time ("Initial" and "Final") and population. All statistical procedures and data preparation were conducted in R (R Core Team, 2019).

\section{RESULTS}

Body darkening. The rate of body darkening ( $b$ values from the linear regressions) did not differ among fish of different sizes $(\mathrm{F}=0.57 ; \mathrm{P}=0.45)$. Also, the interaction between size and population was not significant $(\mathrm{F}=0.25 ; \mathrm{P}=0.85)$. However, the rate of color change differed between populations $(\mathrm{F}=8.95 ; \mathrm{P}<0.001)$. Tukey's HSD test indicated that both populations from the Negro lineage had similar color change rates $(\mathrm{P}=0.98)$. Likewise, the two populations from the Amazonas lineage showed similar responses to exposure to the darker environment $(\mathrm{P}=0.96)$. Significant differences were observed for all comparisons between populations of different lineages (Tab. 1, Fig. 4). The rate of color change in the Negro lineage was, in average, $65 \%$ faster than the Amazonas lineage.

Color change. For all populations, values of Red, Green and Blue differed when comparing initial and final values (Tab. 2, Fig. 5). Changes in blue color were comparatively lower and did not differ among populations, as observed by the interaction term (Fig. 5, Tab. 2). Interestingly, the initial RGB values (Fig. 5 "Initial") indicate that individuals from the Amazonas lineages showed lighter body coloration when maintained during a large period of time to a bright environment (sand).

TABLE 1 I Results of Tukey's HSD test showing all between-population comparisons of color change rate $(\mathrm{N}=56)$.

\begin{tabular}{|c|c|c|c|c|}
\hline Lineage comparison & Difference & Lower & Upper & P \\
\hline Negro 1 - Negro 2 & $6.37^{-5}$ & $-4.42^{-4}$ & $5.70^{-4}$ & 0.987 \\
\hline Amazonas 1 - Negro 2 & $-6.14^{-4}$ & $-1.12^{-3}$ & $-1.07^{-4}$ & 0.011 \\
\hline Amazonas 2 - Negro 2 & $-7.06^{-4}$ & $-1.19^{-3}$ & $-2.18^{-4}$ & 0.001 \\
\hline Amazonas 1 - Negro 1 & $-6.77^{-4}$ & $-1.20^{-3}$ & $-1.53^{-4}$ & 0.006 \\
\hline Amazonas 2 - Negro 1 & $-7.70^{-4}$ & $-1.27^{-3}$ & $-2.63^{-4}$ & 0.001 \\
\hline Amazonas 1 - Amazonas 2 & $-9.21^{-5}$ & $-5.98^{-4}$ & $4.14^{-4}$ & 0.962 \\
\hline
\end{tabular}






FIGURE 4 I Mean and SE representing color change rates for each population of Crenuchus spilurus. Colors represent populations as in Fig. 1. Black and grey bars represent populations of the Negro lineage, red and brown bars represent populations of the Amazonas lineage. Letters represent groupings observed in Tukey's HSD test.

TABLE 2 I Significance values of univariate two-way tests from the MANOVA investigating differences in RGB colors among populations and during initial and final periods of the experiment. Multivariate (Pillai's trace) statistics for the interaction term between time and population: $\mathrm{F}=3.24 ; \mathrm{P}<0.001$.

\begin{tabular}{|c|c|c|c|c|}
\hline Color & Source & DF & $\mathbf{F}$ & $\mathbf{P}$ \\
\hline \multirow{3}{*}{ Red } & Time & 1 & 86.99 & $<0.001$ \\
\hline & Population & 3 & 57.61 & $<0.001$ \\
\hline & Time x Population & 3 & 3.34 & 0.022 \\
\hline \multirow{3}{*}{ Green } & Time & 1 & 94.32 & $<0.001$ \\
\hline & Population & 3 & 45.26 & $<0.001$ \\
\hline & Time x Population & 3 & 3.45 & 0.019 \\
\hline \multirow{3}{*}{ Blue } & Time & 1 & 43.11 & $<0.001$ \\
\hline & Population & 3 & 0.58 & 0.628 \\
\hline & Time x Population & 3 & 0.31 & 0.816 \\
\hline
\end{tabular}

\section{DISCUSSION}

When exposed to a darker environment, populations of the same lineage showed similar rates of body darkening. By contrast, individuals from the two populations of the Negro lineage showed faster rate of color change when compared to individuals from populations of the Amazonas lineage. As such, populations of the lineage that occurs in igarapés of sandy bottom (Negro lineage) showed faster rates of body color darkening when compared to populations that live in environments with a predominance of 

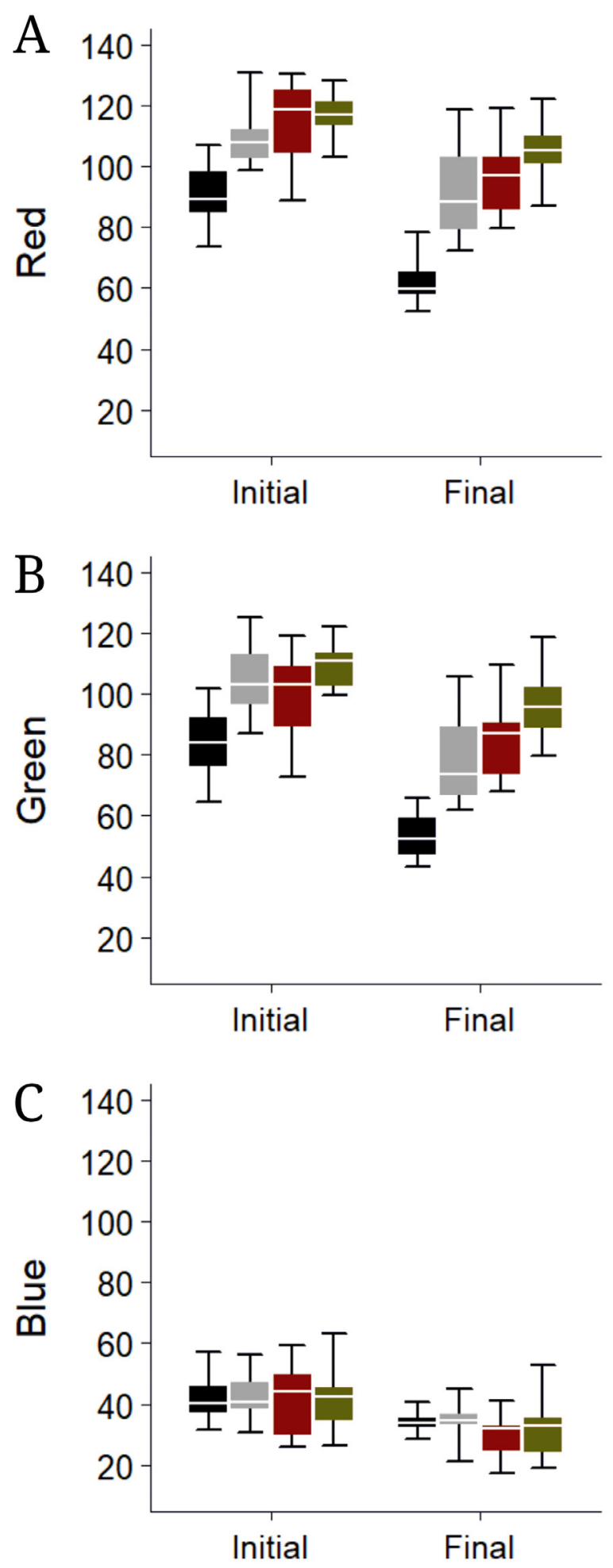

FIGURE 5 I Raw values of RBG; A. Red, B. Green and C. Blue measurements of Crenuchus spilurus body color during the beginning (Initial) and end (Final) periods of the trials. Black and grey boxes represent populations from the Negro lineage; red and brown represent populations from the Amazonas lineage. 
clayey soil. Since sandy bottoms provide a higher contrast against leaf litter, one of the most common objects found underwater in igarapés, we suggest that natural selection stemming from predation pressure favored a faster response of color change in the Negro lineage.

Color pattern can indicate adaptation to the habitats they live in (Macedonia, 2001; Macedonia et al., 2003; Rosenblum, 2005; Robertson, Rosenblum, 2009). During observations in captivity, we noticed a higher amount of individuals with dark coloration in Negro lineage stock tanks. We conjectured that individuals of C. spilurus belonging to the Negro lineage would show higher rates of body darkening, which could potentially represent adaptations to the distinct environments they inhabit.

We used soil samples from locations where the two lineages occur, measured their reflectance to illustrate differences in soil color between these regions and represented the differences in contrast between the soil and typical leaf litter in a spectrogram (Fig. 1). Based on the macroregional study conducted by Quesada et al. (2011), the locations where the studied populations occur can be characterized by distinct soil types: ferralsols for the populations marked in black and grey in Fig. 2, gleysols for the southernmost population (in red) and fluvisols for the westernmost population (in brown). Ferralsols are profoundly weathered and can accumulate high amounts of organic matter (Konhauser et al., 1994; Quesada et al., 2011), whereas gleysols and fluvisols are found in alluvial regions whose soils are typically of higher fertility (Sanchez, 1977; Quesada et al., 2011). The white sand of rio Negro igarapés is usually transported from eroded ancient aeolian or alluvial sandstones (Hardon, 1936; Janzen, 1974), whereas the clayey soil found in locations of the Amazonas lineage are alluvial deposits from recent geological formations such as the Andean cordillera (Sombroek, 1984).

Body darkening or lightening due to variation in the background has long been quantified (e.g. Brown, Sandeen 1948) and the underlying biochemical mechanisms are relatively well understood (Fugii, 2000; Ligon, Mccartney, 2016). Color darkening is derived from the coordinated transport of melanin from the cell center outward, which can be costly in fishes, as it requires both neural and hormonal control (Sugimoto, 2002; Sköld et al., 2013).

The eyes usually mediate the response of chromatophores to variation in the prevailing background color (Parker et al., 1935; Chiao et al., 2015). In dark substrates such as leaf litter, light reaching the retina is mostly provided by direct transmission from the above light source, whereas in light substrates (e.g. white sand), both direct light and reflected light from the bottom reach the eyes and retina. In addition, C. spilurus has paired foramina on the top of the head whose openings lead to an organ that has been termed "frontal organ" (Géry, 1963). While the precise function of this organ remains ambiguous, a histological study suggests that the organ is most likely light-sensitive (Bossy et al., 1965), similar to a pineal gland. Since the pineal gland controls color change in many organisms (Gern et al., 1992; Bertolesi, McFarlane, 2018), the observed differences in rate of color change potentially represent differences in sensitivity of the frontal organ between lineages.

Although color-darkening rates were similar between populations of the same lineage, the initial and final body color (RGB values) were different among populations (Fig. 5, Tab. 2). Individuals of the population closest to the main channel of the rio Negro (black square in Fig. 2) showed a darker initial and final body color, which was 
highly influenced by red and green values (Fig. 5). As such, the ability to maintain distinct body colors might represent adaptation to local conditions, rather than a regional characteristic related to water color.

In previous studies, we suggested that the two main lineages of C. spilurus differ in their ornament coloration and eye size (Pires et al., 2019), as well as in their osmoregulatory requirements for reproduction (Pires et al., 2018). We attributed such differences to the lighting (color bias and backscatter) and hydrochemical conditions provided by black and clearwater igarapés. In this study, however, we find it unlikely that water color could represent, per se, a source of natural selection shaping differences in rates of color change. Since the classification of water types is a result of differences in soil (Janzen, 1974; Sioli, 1984), we find it more parsimonious to attribute the observed differences to differences in the contrast between soil color and leaf litter.

Although background matching most likely represents adaptation in response to predation pressure, body darkening in C. spilurus is also observed during communication among individuals. As such, the reported difference in the rate of color change suggests that communication through color change might differ between lineages. As such, communication between individuals of distinct lineages might be impaired, which can contribute to reproductive isolation. Further studies are needed to assess whether such variation in visual communication constitutes a relevant component of speciation.

\section{ACKNOWLEDGMENTS}

Kalebe Pinto is grateful to CNPq for personal grant. Tiago Pires is grateful to FIXAM/ FAPEAM (\#062.01500/2018). Elio Borghezan is grateful to MEXT (Monbukagakusho

\#183957). Jansen Zuanon is grateful to CNPq for the productivity grant \#313183/20147. This research was supported by JST/JICA, SATREPS. This is contribution \#61 of Projeto Igarapes.

\section{REFERENCES}

- Agrawal AA. Phenotypic plasticity in the interactions and evolution of species. Science. 2001; 294(5541):321-26. https:// doi.org/10.1126/science.1060701

- Bergman TJ, Beehner JC. A simple method for measuring colour in wild animals: Validation and use on chest patch colour in geladas (Theropithecus gelada). Biol J Linn Soc Lond. 2008; 94(2):231-40. https://doi.org/10.1111/ j.1095-8312.2008.00981.x

- Bertolesi GE, McFarlane S. Seeing the light to change colour: An evolutionary perspective on the role of melanopsin in neuroendocrine circuits regulating lightmediated skin pigmentation. Pigment Cell Melanoma Res. 2018; 31(3):354-73. https:// doi.org/10.1111/pcmr.12678
- Bossy J, Delage J, Gery J. Interpretation histo-morphologique de l'organe frontal des Crenuchidae. Paris: C. R. l'Ácademie Sciences Paris; 1965.

- Brown FA Jr, Sandeen MI. Responses of the chromatophores of the fiddler crab, Uca, to light and temperature. Physiol Zool. 1948; 21(4):361-71. https://doi.org/10.1086/ physzool.21.4.30152015

- Carrascal LM, Díaz JA, Huertas DL, Mozetich I. Behavioral thermoregulation by treecreepers: trade-off between saving energy and reducing crypsis. Ecology. 2001; 82(6):1642-54. https://doi. org/10.1890/0012-9658(2001)082[1642:BTB TTO]2.0.CO;2 
- Chiao CC, Chubb C, Hanlon RT. A review of visual perception mechanisms that regulate rapid adaptive camouflage in cuttlefish. J Comp Physiol A Neuroethol Sens Neural Behav Physiol. 2015; 201(9):933-45. https://doi.org/10.1007/ s00359-015-0988-5

- Espírito-Santo HMV, Sodré JG, Zuanon J. He leaps, she beats: the role of social interactions on the overland movements of an Amazonian amphibious killifish. Ecol Freshw Fish. 2018; 28(3):356-64. https://doi. org/10.1111/eff.12458

- Fingerman M. Chromatophores. Physiol Rev. 1965; 45(2):296-339. https://doi. org/10.1152/physrev.1965.45.2.296

- Fugii R. The regulation of motile activity in fish chromatophores. Pigment Cell Res. 2000; 13(5):300-19. https://doi.org/10.1034/ j.1600-0749.2000.130502.x

- Fuller R, Berglund A. Behavioral responses of a sex-role reversed pipefish to a gradient of perceived predation risk. Behav Ecol. 1996; 7(1):69-75. https://doi. org/10.1093/beheco/7.1.69

- Gern WA, Falcón J, Meissl H, Ali MA. Melatonin synthesis by the teleost pineal: an overview. In: Ali MA, editor. Rhythms in Fishes. Boston: Springer; 1992. p.219-22. https://doi.org/10.1007/978-1-4615-3042-8_15

- Géry J. Three new tetras from the upper Rio Negro near Tapurucuara. TFH Magazine. 1963; 12(3):9-15,57-63.

- Gilby BL, Mari RA, Bell EG, Crawford EW, Jun D, Lederer BI, Tibbetts IR, Burfeind DD. Colour change in a filefish (Monacanthus chinensis) faced with the challenge of changing backgrounds. Environ Biol Fishes. 2015; 98(9):2021-29. https://doi.org/10.1007/s10641-015-0424-2

- Hardon HJ. Podsol-profiles in the tropics. Natuurk Tijdschr Nederl Ind. 1936; 96:2541.

- Hayakawa EH, Rossetti DF. Late quaternary dynamics in the Madeira river basin, southern Amazonia (Brazil), as revealed by paleomorphological analysis. An Acad Bras Cienc. 2015; 87(1):29-50. http://dx.doi.org/10.1590/00013765201520130506

- Healey EG. The skin pattern of young plaice and its rapid modification in response to graded changes in background tint and pattern. J Fish Biol. 1999; 55(5):937-71. https://doi. org/10.1111/j.1095-8649.1999.tb00732.x
- Hemmi JM, Marshall J, Pix W, Vorobyev M, Zeil J. The variable colours of the fiddler crab Uca vomeris and their relation to background and predation. J Exp Biol. 2006; 209(20):4140-53. https://doi. org/10.1242/jeb.02483

- Janzen DH. Tropical blackwater rivers, animals, and mast fruiting by the Dipterocarpaceae. Biotropica. 1974; 6(2):69-103. https://doi.org/10.2307/2989823

- Kekäläinen J, Huuskonen H, Kiviniemi V, Taskinen J. Visual conditions and habitat shape the coloration of the Eurasian perch (Perca fluviatilis L.): a trade-off between camouflage and communication? Biol J Linn Soc Lond. 2009; 99(1):47-59. https:// doi.org/10.1111/j.1095-8312.2009.01339.x

- Klinge H. Podzol soils in the Amazon Basin. J Soil Sci. 1965; 16(1):95-103. https:// doi.org/10.1111/j.1365-2389.1965.tb01423.x

- Konhauser KO, Fyfe WS, Kronberg BI. Multi-element chemistry of some Amazonian waters and soils. Chem Geol. 1994; 111(1-4):155-75. https://doi. org/10.1016/0009-2541(94)90088-4

- Leclercq E, Taylor JF, Migaud H. Morphological skin colour changes in teleosts. Fish Fish. 2010; 11(2):159 93. https://doi.org/10.1111/j.14672979.2009.00346.x

- Ligon RA, Mccartney KL. Biochemical regulation of pigment motility in vertebrate chromatophores: a review of physiological color change mechanisms. Curr Zool. 2016; 62(3):237-52. https://doi. org/10.1093/cz/zow051

- Logan DW, Burn SF, Jackson IJ. Regulation of pigmentation in zebrafish melanophores. Pigment Cell Res. 2006; 19(3):206-13. https://doi.org/10.1111/j.16000749.2006.00307.x

- Macedonia JM. Habitat light, colour variation, and ultraviolet reflectance in the Grand Cayman anole, Anolis conspersus. Biol J Linn Soc Lond. 2001; 73(3):299-320. https://doi.org/10.1111/j.1095-8312.2001. tb01365.x

- Macedonia JM, Echternacht AC, Walguarnery JW. Color variation, habitat light, and background contrast in Anolis carolinensis along a geographical transect in Florida. J Herpetol. 2003; 37(3):467-78. https://doi.org/10.1670/159-02A 
- Munguia P, Levinton JS, Silbiger NJ. Latitudinal differences in thermoregulatory color change in $\mathrm{Uca}$ pugilator. J Exp Mar Bio Ecol. 2013; 440:8-14. https://doi.org/10.1016/j. jembe.2012.11.010

- Parker GH, Brown FA, Odiorne JM. The relation of the eyes to chromatophoral activities. Proc Am Acad Arts. 1935; 69(12):439-62. https://doi. org/10.2307/20023069

- Pires THS, Borghezan EA, Cunha SLR, Leitão RP, Pinto KS, Zuanon J. Sensory drive in colourful waters: morphological variation suggests combined natural and sexual selection in an Amazonian fish. Biol J Linn Soc Lond. 2019; 127(2):351-60. https://doi.org/10.1093/biolinnean/blz054

- Pires THS, Borghezan EA, Machado VN, Powell DL, Röpke CP, Oliveira C, Zuanon J, Farias IP. Testing Wallace's intuition: water type, reproductive isolation and divergence in an Amazonian fish. J Evol Biol. 2018; 31(6):882-92. https://doi. org/10.1111/jeb.13272

- Pires THS, Farago TB, Campos DF, Cardoso GM, Zuanon J. Traits of a lineage with extraordinary geographical range: ecology, behavior and life-history of the sailfin tetra Crenuchus spilurus. Environ Biol Fishes. 2016; 99(12):925-37. https://doi. org/10.1007/s10641-016-0534-5

- Quesada CA, Lloyd J, Anderson LO, Fyllas NM, Schwarz M, Czimczik CI. Soils of Amazonia with particular reference to the RAINFOR sites. Biogeosciences. 2011; 8(6):1415-40. https://doi.org/10.5194/bg-81415-2011

- Räsänen M, Neller R, Salo J, Jungner H. Recent and ancient fluvial deposition systems in the Amazonian foreland basin, Peru. Geol Mag. 1992; 129(3):293-306. https://doi.org/10.1017/S0016756800019233

- R Development Core Team. R: a language and environment for statistical computing [Computer software manual - Internet]. Vienna: R Foundation for Statistical Computing; 2019. Available from: https:// www.rproject.org/

- Robertson JM, Rosenblum EB. Rapid divergence of social signal coloration across the White Sands ecotone for three lizard species under strong natural selection. Biol J Linn Soc Lond. 2009; 98(2):243-55. https://doi.org/10.1111/j.10958312.2009.01291.x
- Rosenblum EB. Convergent evolution and divergent selection: lizards at the white sands ecotone. Am Nat. 2005; 167(1):1-15. https://doi.org/10.1086/498397

- Sacchi R, Pellitteri-Rosa D, Bellati A, Di Paoli A, Ghitti M, Scali S, Galeotti $\mathbf{P}$, Fasolo M. Colour variation in the polymorphic common wall lizard (Podarcis muralis): an analysis using the RGB colour system. Zool Anz. 2013; 252(4):431-39. https://doi.org/10.1016/j.jcz.2013.03.001

- Sanchez PA. Properties and management of soils in the Tropics. Soil Sci. 1977; 124(3):187.

- Silbiger N, Munguia P. Carapace color change in Uca pugilator as a response to temperature. J Exp Mar Bio Ecol. 2007; 355(1):41-46. https://doi.org/10.1016/j. jembe.2007.11.014

- Sioli H. The Amazon and its main affluents: hydrography, morphology of the river courses, and river types. In: Sioli H, editor. The Amazon. Dordrecht: Springer; 1984. p.127-65. https://doi.org/10.1007/97894-009-6542-3_5

- Sköld HN, Aspengren S, Wallin M. Rapid color change in fish and amphibians - function, regulation, and emerging applications. Pigment Cell Melanoma Res. 2013; 26(1):29-38. https://doi.org/10.1111/ pcmr.12040

- Sombroek WG. Soils of the Amazon region. In: Sioli H, editor. The Amazon. Dordrecht: Springer; 1984. p.521-35. https://doi. org/10.1007/978-94-009-6542-3_20

- Stevens M, Lown AE, Denton AM. Rockpool gobies change colour for camouflage. PLoS One. 2014; 9(10):e110325. https://doi.org/10.1371/ journal.pone.0110325

- Stevens M, Merilaita S. Animal camouflage: current issues and new perspectives. Philos Trans R Soc Lond B Biol Sci. 2009; 364(1516):423-27. https://doi. org/10.1098/rstb.2008.0217

- Stevens M, Párraga CA, Cuthill IC, Partridge JC, Troscianko TS. Using digital photography to study animal coloration. Biol J Linn Soc Lond. 2007; 90(2):211-37. https://doi.org/10.1111/j.10958312.2007.00725.x

- Stevens M, Rong CP, Todd PA. Colour change and camouflage in the horned ghost crab Ocypode ceratophthalmus. Biol J Linn Soc Lond. 2013; 109(2):257-70. https:// doi.org/10.1111/bij.12039 
- Stuart-Fox D, Moussalli A. Camouflage, communication and thermoregulation: lessons from colour changing organisms. Philos Trans R Soc Lond B Biol Sci. 2009; 364(1516):463-70. https://doi.org/10.1098/ rstb.2008.0254

- Sugimoto M. Morphological color changes in fish: regulation of pigment cell density and morphology. Microsc Res Tech. 2002; 58(6):496-503. https://doi.org/10.1002/ jemt.10168

- Sumner FB. Evidence for the protective value of changeable coloration in fishes. Am Nat. 1935a; 69(722):245-66. https://doi. org/10.1086/280597

- Sumner FB. Studies of protective color change: III. Experiments with fishes both as predators and prey. Proc Natl Acad Sci U S A. 1935b; 21(6):345-53. https://dx.doi. org/10.1073\%2Fpnas.21.6.345
- Tuma MC, Gelfand VI. Molecular mechanisms of pigment cell transport in melanophores. Pigment Cell Res. 1999; 12(5):283-94. https://doi. org/10.1111/j.1600-0749.1999.tb00762.x

- Whiteley AR, Bergstrom CA, Linderoth T, Tallmon DA. The spectre of past spectral conditions: colour plasticity, crypsis and predation risk in freshwater sculpin from newly deglaciated streams. Ecol Freshw Fish. 2011; 20(1):80-91. https:// doi.org/10.1111/j.1600-0633.2010.00461.x

- Zuanon J, Carvalho LN, Sazima I. A chamaeleon characin: the plant-clinging and colour-changing Ammocryptocharax elegans (Characidiinae: Crenuchidae). Ichthyol Explor Freshw. 2006; 17(3):25532. Available from: https://www.pfeilverlag.de/wp-content/uploads/2015/05/ ief17_3_04.pdf

\section{Neotropical Ichthyology}

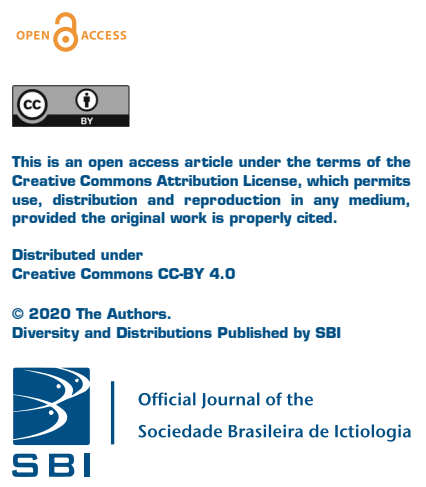

\section{AUTHOR'S CONTRIBUTION}

Kalebe da Silva Pinto: Data curation, Formal analysis, Investigation, Methodology, Software, Writingreview \& editing.

Tiago Pires: Conceptualization, Data curation, Formal analysis, Supervision, Writing-original draft,

Writing-review \& editing.

Gabriel Stefanelli-Silva: Writing-review \& editing.

Bruno Stefany Barros: Funding acquisition, Methodology, Visualization.

Elio Borghezan: Methodology, Resources, Supervision.

Jansen Zuanon: Conceptualization, Funding acquisition, Project administration, Supervision.

\section{ETHICAL STATEMENT}

Experiments were approved by the Ethical Committee for Animal Use in Experiments of the Instituto Nacional de Pesquisas da Amazônia (CEUA 029/2016).

\section{COMPETING INTERESTS}

The authors declare no competing interests.

\section{HOW TO CITE THIS ARTICLE}

- Pinto KS, Pires THS, Stefanelli-Silva G, Barros BS, Borghezan EA, Zuanon J. Does soil color affect fish evolution? Differences in color change rate between lineages of the sailfin tetra. Neotrop Ichthyol. 2020; 18(2):e190093. https://doi.org/10.1590/1982-0224-2019-0093 